\title{
Arabien midt i en
}

\section{systemkamp}

\section{Anders Jerichow}

Både arabiske og vestlige regeringer lægger helst skjul på deres egentlige intentioner, når de drøfter 'arabiske reformer'. Her er koden til de følsomme forhandlinger

Reformer er på dagsordenen overalt i den arabiske verden. Men "reformer" er også en sproglig kode i diskussionen om behovet en modernisering, der kan udvikle sig til en politisk og økonomisk revolution.

Hverken arabiske eller andre regeringer bryder sig officielt om at knække koden og skære ud i pap, hvad de hver især mener, at reformprocessen handler om.

Hvorfor? Fordi det er politisk eksplosivt. Både arabiske og vestlige regeringer er nervøse for stabiliteten i Mellemøsten og Nordafrika. Men deres horisont er forskellig. Hidtil har de været enige om, at stabiliteten var bedst sikret, hvis de nuværende magtforhold forblev uændrede. Det mener de arabiske regeringer stadig. Men i dag mener de vestlige regeringer, at der netop vil blive ustabilitet, politisk ballade, so- ciale revolutioner og konflikter, hvis den arabiske verden $i k k e$ forandres.

Og hvorfor dét? Fordi den arabiske verdens regeringer allerede i dag har svært ved at indfri deres befolkningers ønsker om velfærd og behov for økonomisk vækst, tidssvarende uddannelser og økonomisk og politisk frihed. Derfor taler regeringer og internationale organisationer i koder - bange for at blotte deres egentlige mening med snakken om den arabiske verdens forvandling. Her er den usagte kode:

\section{Reformer}

De arabiske regeringer taler om en gradvis politisk og $\varnothing$ konomisk modernisering af deres samfund under de nuværende regeringers kontrol. Endemålet er uklart.

De vestlige regeringer siger offici- 
elt heller ikke, hvad processens mål er, men taler på det officielle plan gerne om begreber som demokratisering eller folkelig deltagelse, om retssikkerhed, accountability (at stå til ansvar), frihed, civilsamfund og legitimitet. Uofficielt taler de fleste vestlige regeringer derimod direkte om, at den arabiske verdens magthavere skal opgive deres mangeårige magtmonopol og stå til ansvar for deres vælgere ved frie demokratiske valg.

De lægger uofficielt heller ikke skjul på, at deres forventning er, at frie valg vil føre til, at Arabiens nuværende magthavere vil blive skiftet ud. Hvis man lover ikke at citere de vestlige ministre og diplomater ved navn, vil både amerikanske, britiske, tyske, danske og EU-repræsentanter sige ligeud, at også gamle venne-regeringer i Egypten og Saudi-Arabien må vige til fordel for demokratiske alternativer.

Med andre ord: For de arabiske regeringer handler reformer om at stabilisere deres egne regimer gennem forandring - for de vestlige regeringer handler reformer i den arabiske verden på sigt om udskiftning af de nuværende magthavere. Mere følsomt kan det ikke blive. En systemopgør er i gang. Begge parter lader som om de ikke kender den anden parts intentioner.

\section{Dialog og demokratisering}

Både arabiske regeringer og såvel enkelte vestlige lande som internati- onale fællesskaber (EU, NATO, OSCE, FN, Arabiske Liga) anbefaler officielt dialog på tværs af grænser som et nyttigt redskab for udvekslingen af synspunkter om reformer. Spørgsmålet er: Hvem snakker? Og om hvad?

De arabiske regeringer ønsker over en bred front, at dialogen primært skal foregå mellem regeringer. Og hvis andre skal inddrages, skal det ske på vegne af - eller med tilladelse af - regeringerne. De vestlige regeringer anbefaler derimod, at også ikke-statslige organisationer (NGO'er) skal have lov at samarbejde frit på tværs af grænser, $\mathrm{fx}$ arabiske og udenlandske lærerforeninger, fagforeninger, advokatsammenslutninger eller kvindeforeninger.

Uoverensstemmelsen er ikke filosofisk, men konkret. De fleste arabiske magthavere (delvis minus regeringen i Libanon, Marokko og de palæstinensiske områder) insisterer på at kunne overvåge alt samarbejde med udlandet. De vestlige regeringer satser modsat på, at direkte NGO-kontakt vil styrke det arabiske civilsamfund og de arabiske kræfter, som taler for politisk frihed. Med andre ord: Det handler også om magt. De fleste magthavere i den arabiske verden er bange for, at dialogen slippes fri.

De vestlige regeringer stiller ikke lodret krav om demokrati i den arabiske verden, men mere forsigtigt om en gradvis demokratisering. De arabiske regeringer, inklusive Den 
Arabiske Liga har nok accepteret selve ordet "demokratisering", men taler aldrig om demokrati og foretrækker at tale om "øget folkelig deltagelse" i den politiske beslutningsproces. I sidste ende gælder striden om ordet demokrati, hvorvidt de arabiske befolkninger skal have ret til at vælge deres egne politiske ledere og til at organisere sig efter politisk orientering. Med andre ord: Skal den arabiske verdens regeringer anerkende, at de har en opposition - og skal disse oppositioner ikke alene anerkendes som lovlige, men også gives adgang til at udfordre de siddende magthavere i en åben politisk proces, hvor ingen har mere ret til magt end den anden?

Det er tæppet under de nuværende magthavere, der rykkes i...

\section{Folkelig deltagelse}

For at undgå at tale om det følsomme ord "demokrati", taler både Arabiens og Vestens regeringer gerne om at bane vejen for større folkelig deltagelse i politik og økonomi. For de vestlige regeringer er det alene et kodeord for en voksende demokratisering i retning af fuldgyldigt demokrati på længere sigt. For de nuværende arabiske regeringer kan "folkelig deltagelse" derimod rummes inden for de nuværende politiske strukturer, hvor delvis frit valgte forsamlinger i stor udstrækning kun tjener som rådgivende for den øverste magt. Med andre ord: Folkelig deltagelse hjælper regeringer til at omgå det følsomme spørgsmål om, hvorvidt arabiske befolkninger har krav på et egentligt demokrati.

\section{Accountability}

Accountability er et solidt engelsk ord for at stå til ansvar. Vestlige regeringer fremfører hyppigt i deres arabiske reform-idéer, at Mellemøsten og Nordafrika har brug for accountability. Det skæres nødigt ud i pap. Men idéen er klart, at magthaverne skal stå til ansvar over for deres befolkninger. Det skal de gøre både politisk og økonomisk. Arabiske regeringer anvender ikke gerne begrebet, men forsøger i betydelig udstrækning at indfri krav om accountability ved at lade den $ø$ konomiske politik og nationale budgetter m.m. debattere åbent.

For de vestlige regeringer hænger accountability i sidste ende sammen med, at arabiske regeringer skal kunne væltes, hvis deres dispositioner ikke huer deres befolkninger. I første omgang satser de vestlige regeringer på at kræve åbenhed i arabiske forvaltninger og på at eksponere og forbyde korruption. I næste omgang håber vestlige regeringer, at Arabien vil acceptere indførelsen af ombudsmandsordninger med mulighed for at overvåge al offentlig administration på borgernes vegne (den første arabiske ombudsmandsinstitution overvejes nu i Jordan). Og på længere sigt vil vestlige rege- 
ringer reelt forvente, at arabiske regeringer, både enkelte ministre $\mathrm{og}$ hele regeringer, skal kunne væltes og erstattes både ved faste terminer og hvis de ikke kan opretholde en parlamentarisk opbakning.

Med andre ord: Accountability er dødsensfarligt for de eksisterende magthavere i Arabien.

\section{"Parlamenter"}

Der er indført parlamenter i samtlige arabiske stater. På den Arabiske Halvø er det især sket i form af officielt "rådgivende forsamlinger" (majlis al-shoura). Forsamlingerne skal overalt give indtryk af en folkelig forankring for magtudøvelsen i landet.

I praksis er kun parlamenterne $\mathrm{i}$ Libanon og det palæstinensiske selvstyre valgt ved fri stemmeafgivning (om end blandt palæstinenserne under israelsk besættelse) for alle borgere. I ingen arabiske lande er der fuld partipolitisk frihed og fri adgang for partier til at deltage i valg, ligesom ingen parlamenter kan udskifte de øverste politiske magthavere.

I dialogen med omverdenen betoner arabiske regeringer disse forsamlinger, som i stort tal allerede indgår i internationalt samarbejde med frit valgte parlamenter. Vestlige regeringer er tilbageholdende med at kræve fuld partipolitisk frihed, fordi de - ligesom arabiske regeringer - er bange for, at frie valg kunne bringe revolutionære eller konservative religiøse bevægelser til magten. De vestlige regeringer fremfører i stedet krav om stemmeret for både mænd og kvinder og om overvågning af valghandlinger.

Med andre ord: Eksistensen af parlamenter kan i deres nuværende form tjene som politisk figenblad for trængte arabiske regeringer. For vestlige regeringer er rigtige parlamenter selve målet for fremtidens arabiske magtforankring.

\section{Civilsamfund og NGO'er}

Med civilsamfund menes et fintvævet netværk af ikke-statslige og ikke-militære politiske, sociale og økonomiske strukturer. Vestlige regeringer vil gerne styrke de arabiske civilsamfund for at skabe sammenhængskraft og større stabilitet, men de vil også gerne styrke de arabiske civilsamfund for at styrke de ikke-statslige strukturer.

De nuværende arabiske regeringer taler gerne om civilsamfundet $\mathrm{i}$ dialogen med udenlandske regeringer, men er generelt skeptiske over for udenlandske ønsker om at udvikle det arabiske civilsamfund. Med andre ord: Civilsamfundet er et kodeord for den regerings-uafhængige sammenhængskraft.

De ikke-statslige organisationer NGO'erne - er de demokratiske samfunds hjerteblod, mens de i totalitære samfund, også i Arabien, er trusler mod magthaverne. Vestlige re- 
geringer forsøger bestandigt at få arabiske regeringer til at acceptere, at NGO'er fra de to verdener frit skal kunne samarbejde. De arabiske regeringer stritter imod. I de fleste arabiske samfund skal NGO'er stadig have licens fra staten til at kunne eksistere og samarbejde med NGO'er i andre lande.

Det har i mange arabiske lande ført til oprettelsen af såkaldte "GONGO'er" (Governtment-Organized Non-Governmental Organizations), reelt en slags regeringsstyrede organisationer, som skal gøre det ud for folkelige bevægelser. De vestlige regeringer forsøger i stor udstrækning at støtte et politisk, fagligt, økonomisk og professionelt samarbejde mellem folkelige bevægelser på tværs af arabisk-vestlige grænser. De arabiske regeringer har for længst gennemskuet ideen.

Med andre ord: NGO'er er blevet et redskab i systemkampen.

\section{Frihed og retssikkerhed}

Både arabiske og vestlige regeringer betoner frihed. For de arabiske regeringer handler det helst om national frihed til at organisere og udtrykke sig frit og uafhængigt af internationale krav ("på grundlag af den arabiske verdens egen kultur", defineret af de nationale magthavere).

For de vestlige regeringer er frihed principielt en individuel ret for borgere, politisk og økonomisk. Men blandt arabiske dissidenter og demokratiforkæmpere mødes begge dele med mistro, fordi de aldrig har valgt deres nuværende magthavere og aldrig bedt dem om at tale på deres vegne, og fordi de i årevis har vidst, at deres nuværende magthavere i stor udstrækning var understøttet af vestlige regeringer.

Hver gang nogle nævner ordet "frihed", kan spørgsmålet i Arabien stilles: For hvem? For regeringer eller for befolkninger eller for individuelle borgere?

Retssikkerhed er et vestligt yndlingsord, i Arabien et omstridt begreb. I samtlige internationale statusopgørelser over menneskerettigheder savner arabiske borgere retssikkerhed med uafhængige, frie domstole, ret til en advokat, åbne retssager, appelmuligheder osv.

Vestlige regeringer anbefaler i deres dialog med arabiske partnere gerne en forstærket indsats for at styrke uddannelsen af dommere og for at styrke borgernes kendskab til lov og ret. Arabiske regeringer vil nødig selv stå til ansvar over for uafhængige domstole.

\section{Politisk legitimitet}

Politisk legitimitet er et dødsensfarligt begreb for de nuværende arabiske magthavere, hvoraf kun den libanesiske og palæstinensiske regering er valgt ved en fri stemmeafgivning.

Vestlige regeringer har gerne begrebet med i deres erklæringer om arabiske initiativer. I den arabiske 
verden gælder, at ingen af de nuværende magthavere, netop bortset fra dem i Libanon og det palæstinensiske selvstyre, kan hævde at bygge på fuld folkelig legitimitet, enten fordi der slet ikke er afholdt valg eller fordi retten til at deltage i valghandlinger har været begrænset.

I samtlige arabiske monarkier alle arabiske stater ved golfkysten plus Jordan og Marokko - har kongefamilierne den reelle magt og synes ikke interesseret $i$ at overdrage magten til folkelige repræsentanter.

De øvrige arabiske stater er officielt republikker. Ikke desto mindre har de samme magtkliker ved hjælp af militæret fastholdt magten i disse lande i årtier. Med andre ord: Legitimitet er uhjælpeligt knyttet til spørgsmålet om de nuværende regeringers lovlighed og politiske opbakning.

\section{Religionsfrihed}

Kun tøvende er vestlige regeringer begyndt at medtage retten til religionsfrihed i dialogen med arabiske partnere.

I dag siger USA ligeud i State Departments årbog om religiøs frihed, at noget sådant slet ikke eksisterer i Saudi-Arabien, som i mange år har været en hjørnesten for amerikansk Mellemøst-politik.

I de fleste arabiske samfund er ikke alene de ikke-muslimske mindretals vilkår et ømtåleligt spørgsmål. Mindst lige så følsomt er forholdet mellem forskellige muslimske samfund og forholdet mellem stat og religion. I netop dette spørgsmål har arabiske og vestlige regeringer $i$ årevis været enige. Begge parter frygter religiøse bevægelsers ambitioner og indflydelse.

Og modsat har arabiske muslimske aktivister i stort tal set deres egne regeringer og vestlige regeringer som ét fedt, en fælles fjende.

Arabiske regeringer er ofte bange for, at det religiøse samfunds sociale netværk er en rival til de hyppigt svage stater. Og vestlige regeringer har med støtte fra de fleste arabiske magthavere ofte set moskeer og religiøse netværk som rekrutteringsgrundlag for politisk-religiøs vold og terror.

Både arabiske og vestlige regeringer overvejer mulighederne for at bygge bro til det religiøse samfund, som - hvad enten man bryder sig om det eller ej - udgør det mest udbyggede stykke civilsamfund i Arabien i dag.

Hvis arabiske magthavere tillader frie demokratiske valg, vil religiøse bevægelser og partier mange steder stå som de første valgs vindere. De vestlige regeringer tøver. De nuværende arabiske regeringer kunne ikke forestille sig noget værre end et samarbejde mellem udenlandske regeringer og netop de stærke religiøse netværk.

Med andre ord: religiøse netværk er jokere i reformprocessen, indadtil og udadtil. 
Islam

I alle arabiske samfund dominerer islam, kun Libanon har en virkelig stor kristen minoritet. Men alle arabiske samfund er også verdslige, ingen har præsteskabet øverst i det politiske hierarki. I alle stater styrer magthaverne religionen, hyrer præsteskabet og kontrollerer de lokale menigheder osv. De vestlige samfund, som i voksende grad har fået deres/vores egne muslimske minoriteter, har derimod svært ved at hitte ud af islams rolle, både hjemme og ude.

Hvem repræsenterer islam? Religionen har ikke noget telefonnummer og ikke en hierarkisk struktur. De arabiske regeringer forsøger ved deres kontrol af de religiøse menigheder at monopolisere deres versioner af islam, men også at undertrykke rivaliserende bevægelser inden for de muslimske samfund.

Både i Mellemøsten og i den omgivende verden står islam alligevel over for voksende krav om nyfortolkninger af religionen og om ind- fortolkning af islam i moderne demokrati. Det udfordrer de herskende strukturer i såvel den arabiske verden som i de muslimske samfund.

For regeringer i såvel Arabien som i den omgivende verden kan det religiøse samfunds udvikling få stor betydning. Arabiske regeringer søger at fastholde kontrollen. Vestlige regeringer vil søge efter nye religiøse ledere, som vil anfægte gamle totalitære strukturer og indgå i verdslige, demokratiske fællesskaber.

Med andre ord: islam er en varm kartoffel, som arabiske regeringer ikke tør andet end at holde under låg. Dét har vestlige regeringer i årtier støttet - nu søger de måder at "modernisere" de muslimske, religiøse samfund.

Anders Jerichow er forfatter til bogen 'Arabiens nye frihedskamp', som Det Udenrigspolitiske Selskab planlagger at udgive i begyndelsen af 2006. Han er kronikredaktør på Politiken 